\title{
New Paradigms in the Exercise of Universal Rights and Freedoms
}

\author{
Milan Palević, Ph.D. \\ Faculty of Law, Univesity of Kragujevac
}

Dejan Matić, Ph.D.

Faculty of Law, University of Kragujevac

\section{Doi:10.5901/mjss.2013.v4n9p709}

\begin{abstract}
The guarantee of a successful development of any modern, democratically oriented society, largely rests on continuous and fuller realization of a broad range of human and minority rights and freedoms. Current social trends in the world, reflected mostly in pervasive process of globalization, put modern society before a number of challenges which have their immediate impact on all aspects of social life. Therefore, reflection on, and thus consequently realization of universal freedoms and rights must necessarily start from the changes caused by globalization, both in general, worldwide scope, and in the content and character of humanity, in the context of marking a new phase in the evolution of modern society, with subsequent, far-reaching changes in the position of the man and the realization of his dignity. The complexity of social relations in the modern world is expressed by, among other things, disparities and inequalities among people. These disparities and inequalities gain intensity in the sphere of economic life, particularly in terms of the current global economic crisis. They are shown in an increase in unemployment, large social differences, and an increase in poverty. All these phenomena are global in scope and shaking all modern society, almost without exception, undoubtedly influencing the level of realization of human and minority rights and freedoms, even in those communities which strongly rely on their sincere and full respect. This paper aims to point out the necessity of full realization of all human rights and freedoms in the current social situation, since it is where an essential foundation of the re-development of a new, global society, undoubtedly based on stable foundations of democracy, tolerance and economic development, lies.
\end{abstract}

Keywords: human rights, globalization, global economy, decent work

\section{Introduction}

Human rights represent a specific body of natural rights inherent to every human being on the basis of the simple fact of birth. These are universal, inherent and inalienable rights based on moral vision of human nature itself. Formally, they consist of a set of principles, standards and norms aimed at their protection and realization of life and spiritual ambitions of every man individually (Đorđević \& Palević, 2010).

Although the internationalization of the questions about human rights protection is related to the 19th century, a genuine belief that "regimes that violate the rights of their subjects become internationally aggressive and dangerous to the peace and their neighbors", was supported only after the Second World War. Then, at last, it was realized that human rights violations, in addition to being an attack on a man- individual, also represent a potential threat to international peace and security, which was, perhaps, the key factor in opting of states not only to study human rights, but also to regulate them by special legal rules and to see them as corpus separatum of public international law (Palević \& Ganić, 2010).

Respect for and protection of human rights are classified in the order of goals priority of the United Nations (Article 1 of the UN Charter). Universal Declaration of Human Rights (1948) gave a plenary confirmation of acquired civilisational belief that "recognition of the inherent dignity and inalienable rights of all members of the human family is the foundation of freedom, justice and peace in the world" (Preamble). Through these, "basic documents", the man and his rights entered the international scene, not only as subjects of an individual, vis-à-vis protection of the state, but as subjects of interest and protection of the international community as a whole.

Apparent promotion of a commitment to protect human rights and broad regulatory actions in this matter, as well as the basic characteristics of the post-war development of international society, necessarily lead to a different (more positive) consideration of the position and role of an individual and human groups in all aspects of social life, including 
the economic-social sphere, where the modern man is most flagrantly faced with different effects of globalization.

\section{Economic globalisation}

At the empirical and ideologically neutral level, globalization reflects an objective, spontaneous, global process of major innovations propagation: the IT revolution and superior social forms. However, seen from the perspective of world politics, geo-strategic interests and current (transitional, post-Cold War) constellation of power, it is often perceived as a factor of operationalization of the idea of the West domination, or the "Americanization" of the world, and as a "tailwind" of neoliberal capitalism that leads to fragmentation and deepening of the gap between the worlds and civilizations. In this regard, it can be often heard that globalization, in fact, came from the western, capitalist countries in an attempt to master the planet and to organize all humanity in function of their specific interests and not the interests of some abstract humanity.

The process of globalization inevitably, and actually, leads to fundamental changes in social status and importance of the state. Politically, states in the process of globalization are constantly renouncing their own sovereignty, going more slowly or faster into differently designed alliances or supranational organizations. The economic globalization process, in relation to the state, encourages and causes the incorporating of national economies of the world into a single unique economic system.

The global economy, one of the most important parts of the global system, which we project as the end point of the universalization of globalization process, is a unique and contradictory system of rich and poor states where countries join unevenly developed, and in which these inequalities are "systemically" maintained. It is based on the rapid transfer of capital, informational openness of the world; technological revolution; devotion of industrially developed countries to liberalization and mobility of goods and capital, communications convergence and new forms of transportation and communication technologies. In a certain sense, the global economy is a planet conquest by transnational corporations and in the interests of corporations that dominate national economies (Reirnet, 2006).

Economic globalization is expressed through the expansion of the area of economic power "by conquering new territory", that is, sources of raw materials and markets, without the use of force, by the use of money. As the money is not reproduced in the "spatial scarcity", globalization is emerging as the only logical and meaningful way to make money gain momentum and continuously generate profit "by peaceful means". This process is enabled by the application of high technology, market competition and the dominant form of capital movement in the form of money - money, which enabled the formation of overall financial-information technology (Boriko, 2002).

With the "economic globalization", neoliberal capitalism finally becomes global capitalism dominated by transnational corporate interests, in which the role of the state is reduced, mass culture is widespread and information reality is achieved (Marković, 2008). The money in it is positioned as a supreme ruler, the absolute value and the myth are created out of profit efficiency and maximization. New trinity, the market-competition-money is directed towards winning the supreme authority which will manage the transactions of planet, imposing its own rules and its unifying norms, despite the different cultural patterns, values and identities that exist in the international area. Neoliberal networking of planet was done on the basis of privatization, deregulation and liberalization, i.e. the creation of a free market, with the promise that all who submit to its requirements will be „blessed by earthly wealth”. But the realization of this promise is not so simple and easy. The gap between the principles of profit and principles of humanism exists in the very basis of capitalism, in every form of its development, including the global neoliberal capitalism. It is again proved that the power of money tramples over human dignity, insults his honor and destroys hope.

\section{Decent work}

The study of the phenomenon of globalization, as a planetary social process, and the main features of global capitalism is impossible without considering questions of the development of technical basis of work and changes in its content, together with the consequences that accompany it.

Striving for greater rationality and productivity, with the aim to assume extra profit, capitalism has served as a stimulus for the development of productive forces. The third technological revolution created a computer technology that changes the position of man in man-machine system. Technological globalization, as a subsystem of the overall process of globalization leads to the replacement of human labor by machine, initially in jobs that do not require the capacity of man, and later in jobs that require this capacity. From the person who runs the machine, the man becomes its monitor. In the working environment in which micro-electronic devices and chip technology prevail, there is a decrease in the 
quantity of human labor. Confronting workers with the material components of the labor not only reduces, but almost disappears. These and other changes in the content of human labor result in a loss of sense of purposefulness of work, of self-esteem and self-evaluation, feelings that, as a rule, all human beings to a greater or lesser extent have.

However, besides the negative, the changes in the content and character of the labor have its positive effects. They are reflected primarily in ensuring that knowledge is becoming the main developing resource of global capitalism, and to the extent that it becomes its key feature. In the so-called "knowledge capitalism", knowledge and skills have become the only resource of sustainable, long-term, compatible advantage of corporations, but also of larger social structures. Intellectual capital is becoming a reality of economic and social life, which consequently leads to the intellectualization of human work activity. Knowledge delivery, not muscle strength becomes the central value and importance of an individual. The man with its working activities expresses less by physical strength and more by intellectual abilities and capacities. It is a new, positive face of neoliberal capitalism, conceived more on intellectual and less on money-physical capital. It is based primarily on the faith in the market, and faith in the individual. Because of that, people - the holders of knowledge and skills - should be treated as thinking beings, capable to, thanks to their «life force», produce and improve their lives in specific socio-space.

In recent studies of man's position in the global economy, two relatively new approaches in the consideration of human potentials have found their place:

\section{1. human potential development index (HPDI) and}

\section{2. human life force index (HLFI).}

Considerations on the human potential development index and human life force index, are created in the context of the need for a more productive and profitable human activity in a time when it is intelligized, demanding that the people - the holders of knowledge and skills, in work engagement are perceived and treated as conscious, thinking and free beings, with personal integrity protected in all its manifestation variations.

Human potential development index has the four paradigms: $a$. productivity - growth; $b$. rationality - the possibility to realize the ability to use resources, $c$. stability - secure access to the achievements of civilization of present and future generations, $d$. expansion of possibilities - development that is achieved not only in the interest of people, but of their straining also. The indicators of the index of human potential development are: life expectancy and real gross domestic product per capita. Taken together these data incorporate three main characteristics: $a$. healthy living, $b$. knowledge and c. life standard worthy of a man. Starting from the basic features of the global economy, in the new approach to the problem of human factors, it would be useful, it seems, to supplement the four paradigms of human potential development index with the fifth paradigm: security - a statement on working conditions in which the integrity of the man is not compromised.

Human life force indicators (HLFI) are categories of vitalist sociology that has developed a system of indicators of the development of life force of a man, as biopsychosocial being, expressing his production capacities and improving their own lives in specific socio-historical and socio-cultural conditions. In accordance with tradition of HLFI implementation and evolution of man's life force, indicators of its development are also formulated. First, the mean value of the indicators of the development of physical, mental and social capacities of human beings. Second, the existence of a basic set of indicators of physical, mental and social health which reflects the development of basic human forces, created in all basic spheres of social life - economy, politics, social and spiritual-cultural environment. With the integration of these factors, the optimization of the effort in evaluation of human life force development, as a whole, as well as in specific areas of social life, is allowed.

It was on the Philadelphia Conference (1944) that ILO took on the responsibility to prepare a program whose implementation will ensure working conditions in which employees would feel satisfaction with the work, showing the full extent of their capacities contributing to the general welfare. Based on these and similar statements from the ILO documents, in an attempt to establish harmony between the content of human labor and human dignity, determining of contents of a decent, i.e., dignified work started.

Decent work is defined as a highly effective work in good production, social, working and safe conditions with filled capacities that make every employee satisfied, allowing them to utilize fully their abilities and skills. It is a well-paid work in which the rights and dignity of workers are protected, with which they actively engage in the activities of the organization.

In conditions of a contradictory global system, achieving of this understood and polyaspectedly specified decent work is discussed a number of times and with more people, and the most comprehensively in the Report of the DirectorGeneral of the International Labour Office (1999). The report said that decent work is a global demand and political directive and that much of our future depends on our ability to find a solution to this problem, i.e. achieving decent work. 
The work -it was said in the Report is a landmark more than the achieved goal, and it is pointed to the possibility of transforming it into a global goal. Also, it is pointed to the need to achieve four strategic tasks and conditions for conversion of decent work into a global goal. These tasks are: 1. expansion of employment opportunities; 2. determining the system of social employment; 3 . development and strengthening of the social dialogue system and 4. realization of the protection of the right to equality.

In discussions of "decent" work, it is often pointed to it as being less an accomplished goal and more the orientation to achieve this goal. However, not only for methodological, but also for practical reasons, it is necessary to expose, in a more or less systematic fashion, the components of goals to which realization we should strive for. Thus, a concrete contribution is given to the definition of decent work and the indexation of its achievement is facilitated. In this sense, it seems reasonable to say that "decent" work is: highly qualified work; that it takes place in good production and social conditions and at full capacity; that it allows the expression of knowledge and skills of participants; that it is work in a safe environment with the rights and dignity of man protected; that it is adequately paid, and that the engagement of employees in the organization of work makes employees satisfied participants in work activity.

This conceptual definition of "decent work" undoubtedly allows all people to almost entirely express themselves through their work as free, autonomous and creative subjects. Thus specified human activity does not lead only to the increased productivity, but also to the undeniable realization of a man as a generic self-conscious being. Consequently, there is no doubt that due to the logically necessary economic growth and higher productivity, "decent work" becomes unavoidable factor in harmonizing the economic growth and social progress.

Considering that the economic activity takes place in the global economy, that is, in a global system of unique market, followed by differences among states in terms of their economic strength, development and organizational forms, the inevitable impact of these factors on the realization of the concepts of "decent work" as a global process cannot be denied. We tend to argue that precisely two global problems of the modern world society, more than significantly influence on impracticability, i.e., difficult realization of this concept. These are, in our opinion, the problems of employment (i.e. unemployment) and poverty. It is hard to deny the mutual dependence and connection of these two huge problems, and the consequent need to address them at the global level, as a necessary precondition for the realization of "decent work". It is in this sense that we should understand the views of the United Nations General Assembly (2000) on social development and support to the Program of the ILO on "decent work", as well as the attitudes of its sessions of 1970 on the readiness to support fair globalization, securing goals of full and productive employment and decent work, while ensuring respect for fundamental principles and rights in the area of labor.

Given the need to accept the realization of "decent work" as a global problem, it is possible to formulate a theory about a new concept of governing a society characterized by growth of dynamics and complexity of social relations, by a combination of statements on indexes of development of human potential, human life force and content of "decent work". The regulation of these relationships necessitates "imagination" in the reorganization and the organization of the society, including the change of the concept of society itself, i.e., the transition from the society of men-producers into the society of men-creators. This "imagination" as we see it, must necessarily move in the direction of overcoming confrontational relations in the sphere of labor, finding new forms of social partnership and joint and several liability of employees and employers in the economic development and general social progress.

The problem of establishing „decent work" must be considered not only globally, but also at the level of smaller areas of social organization, and the level of institutional forms of work organization (companies, corporations, etc.). That is why we need critical consideration of institutional forms of organization of human work activity, particularly in the economic sciences, in order to find new forms of organization, in compliance with changes in the content and character of the work, which promote knowledge and skills as the most important resource for development, as intellectual capital and intellectual property. These new institutional forms of organization of work activities should ensure their own compliance with all the possibilities offered by the intellectual capital in terms of achieving "decent work" and the high productivity of business based on it, as the main competitive advantage in market conditions. Therefore we believe that the possibility of employees to participate in the management of institutional forms of work organization is of special importance. With this approach in the institutional forms of work organization, economical determinism disappears, in a sense, and social-cultural determinism is made.

\section{Instead of a Conclusion}

Globalization and global capitalism require new, empirically and epistemologically verified answers, not just to the traditional philosophical question of man's position in the world and the cosmos, but also of its place in the global 
economy and work environment that is shaped by it. In this regard, we should critically, with analytical and deductive aspects observe the economic reality of today with no pre-set concepts and models that tend to adapt the same reality (referring specifically to the economic reality) to its given content. This methodological approach is also, it seems, necessary in the research of global neoliberal capitalism, characterized by market as a kind of deus ex machina in the regulation of trade and effects, all in the light of the knowledge that the modern market mechanism affects most individual economies due to disregard of social and human factors. The market does not exist without people and it is an important part of the structure of social relations. Consequently, the perception that people are assets whose working activities exclusively serve social progress should be critically review and rejected, and theoretical concepts should be appreciated in which the working activity of people contribute to general social progress, but they also express themselves as a creative and free beings, realizing conditions of their material existence and social status by stepping into mutual relations. In these relations people naturally express their ideological and political orientation, position themselves in the political body of society, building their place in the categorical system of values and an attitude toward the system. Therefore, the realization of "decent work", as much as it seemed as a social utopia of postindustrial neoliberalism, should not be left "for better days" to fulfill the missing sociopolitical references to its realization. As a strategic goal, "decent work" can be achieved in phases. Precondition for successful implementation is the acceptance of its importance as a strategic goal of achieving humane development of society.

\section{References:}

Boriko, A. (2002). NEXT - small book on globalization and the future of the world. Belgrade, Serbia: Narodna knjiga Alfa.

Đorđević, S., Palević, M. (2010). Law on Prohibition of Discrimination (legal analysis). Kragujevac, Serbia: Faculty of Law University of Kragujevac.

Marković, Ž. D. (2008). Global economy. Niš, Serbia: Faculty of Economics University of Niš, 37-90.

Palević, M., Ganić, S. (2010). The influence of human rights on the status of an individual in the International law. In Gašparovič, I. (Ed.), Harmonization and Unification of Law in the European Context: Section of European Law and Comparative Jurisprudence; Collection of Papers from the International Scholastic Conference Law as a Unifying Factor of Europe - Jurisprudence and Practice (pp 337-347). Bratislava, Slovakia: Faculty of Law Comenius University.

Reirnet, E. C. (2006). Global economy. Belgrade, Serbia: Čigoja štampa. 